always been that Venus in March of that year was invisible, while she ought to be a morning star in Pisces, which she was twelve months later. But it was pointed out six years ago that Dante very likely took the position of Venus from a perpetual Almanac compiled by a Jew. In the Hebrew original all the cycles begin in $r 301$, while in the Latin translations they begin in 1300 , except those of Venus and the sun, which begin with r 301 . It is therefore quite possible that Dante took the places of Venus for I 301 , believing them to be for I 300 , and Angelitti's tempting theory must therefore be abandoned, to the regret of the author of the present work, in which we cordially join.

J. L. E. D.

\section{FOUNDATIONS OF SYSTEMATIC BIOLOGY.}

Abstammungslehre-Systematik-PaläontologieBiogeographie. Unter Redaktion von R. Hertwig und R. v. Wettstein. Pp. ix +620 . (Leipzig and Berlin: B. G. Teubner, I9I4.) Price I2 marks.

"TO no nation, except the German," says 1 General von Bernhardi, "has it been given to enjoy in its inner self that which is given to mankind as a whole. We often see in other nations a greater intensity of specialised ability, but never the same capacity for generalisation and absorption." That is the German way of expressing the German capacity for organisation and compilation, which, when it produces works such as that of which the present volume is a portion, performs a valuable service to the intellectual world. The whole work, "Die Kultur der Gegenwart," purports to be a systematic survey of modern culture on a historical basis, portraying the fundamental achievements of the diverse centres of civilisation in their relation to the whole as it exists now or promises to be developed hereafter. The division allotted to the organic natural sciences comprises four volumes, of which this is logically the last. Volume ii., the only other as yet issued, was reviewed by us in April, I9I4 (vol. xciii., p. Ior).

In view of the claim mentioned above, it is interesting to note that the contributors are not all German, for besides R. Hertwig, L. Plate, A. Brauer, A. Engler, and K. Heider, there are the Austrians, R. v. Wettstein and O. Abel, the Dutchman, W. J. Jongmans, and the Dane, J. E. V. Boas. It is, moreover, pleasing to observe that these authorities do not neglect the workers in other countries, but, by the lists of leading books which they furnish, prove that in this department, at all events, all nations take their share, and that the fellow-countrymen of NO. 2353, VOL. 94]
Darwin have no reason to feel ashamed. The truth is that, though in art there must be nationality, science has become absolutely international: the observation made by a Dane to-day is checked by a Japanese to-morrow, and an American then carries it a step further.

It would not be possible, even in several pages, to give a critical summary of what is itself a summary, and an admirably critical one, of the whole world's work in that which, from a theoretical point of view, is the most important branch of biology. Few men could have written a more lucid, a more just, or a more thought-compelling account of the doctrine of descent than Prof. Richard Hertwig. "It is," he concludes, "the only possible theory ... and the one that has given the weightiest impulse to this science. The crowd of exact investigations that has resulted from Darwin's writings may seem to have gone beyond or even away from him; but these last years show an unmistakable return to the views of the great British naturalist."

The articles on geographical distribution by Profs. Brauer and Engler, on palæontology by Profs. Abel and Jongmans, on the classification and phylogeny of plants by Prof. von Wettstein, and on the phylogenies of invertebrate and vertebrate animals by Profs. Heider and Boas, may be open to criticism in details, but afford on the whole admirable digests, made interesting by the fact that the distinguished authors have taken their own lines on disputed questions. It is, however, the chapter by Prof. L. Plate on the principles of taxonomy with special reference to the classification of animals that fills the most urgently felt want. The mere description of new species, as carried out by too many writers, is far from being good systematic work, or even scientific work at all. But the true systematist has perpetually to exercise his mind with the most complicated problems of his science, cannot venture to eschew metaphysics, and has even to rival the poet in his use of the imagination. All systematists who would understand their own task should read Dr. Plate's illuminating review of modern methods and ideas. F. A. B.

\section{SCIENCE, METAPHYSICS, AND EDUCATION.}

(1) The Anthropology of the Greeks. By E. E. Sikes. Pp. xii +112. (London: David Nutt. I9r4.) Price 5s, net.

(2) The Mechanistic Principle and the Non-mechanical. By Paul Carus. Pp. I25. (Chicago and London: The Open Court Publishing Company, I9I3.) Price $4 s$. net.

(3) Transformisme et Créationisme. By Prof. 
J. L. de Lanessan. Pp. 352. (Paris : Librairie Felix Alcan, I914.) Price 6 francs.

(4) A History of Education in Modern Times. By Prof. F. P. Graves. Pp. xv +4io. (New York: The Macmillan Company; London: Macmillan and Co., Ltd., I9r3.) Price 5s. net.

(5) Methodik und Technik des naturgeschichtlichen Unterrichts. By Prof. W. Schoenichen. Pp. xiv +6 I +30 plates. (Leipzig: Quelle and Meyer, I9I4.) Price I2 marks.

(I) THERE is always an interest, and often 1 no little instruction, to be derived from a study of the science and religion of ancient civilisations, especially when considered in their inter-relations. One of the newest of sciences, anthropology, appears to be rooted in the earliest strata of thought, as, for instance, among the natives of Central Australia. Greek speculation upon the origin and development of mankind was not limited to fairy-tales of the Golden Age type. From Herodotus onward their best minds had a very shrewd idea of the real process, such as we have come to see it. Lucretius repeated, with original observations of his own, the anthropological theories of Epicurus. But these are the culmination of Greek scientific thought in this direction. They were foreshadowed by Aeschylus and Herodotus, and developed later. It seems that the Greeks, who certainly had considerable opportunities, thanks to their trade, travel, and warfare, collected a considerable body of data relating to savage and barbarous peoples in the west, the east, and the south. There was, of course, another school, the Platonic; it was true then, as ever since, that a man is born either an Aristotelian or a Platonist. Then, too, as now, the Platonist built upon teleology. Mr. Sikes has done well to collect every statement in Greek literature that throws light on the scientific ideas of that "most quick-witted and curious of human races," concerning the origin and development of their own species. It should be read by all anthropologists, whether their Greek is "less" or more.

(2) But the Greek mind was more interested in the problems of cosmic and ultimate metaphysics, and the issues waged between Determinists and Creationists, or whatever the two fundamental types of mind be termed. These issues seem destined to be eternal. So Dr. Paul Carus, following up his interesting propaganda of many years, writes some notes upon representative quotations from exponents of both sides. "Mechanicalism" and teleology are first contrasted. The "contributions," as they may be called, to his volume include some very interesting expressions of opinion, especially Mark Twain's philosophy and La Mettrie's famous exposition of man "as a machine." It is curious that La Mettrie, when persecuted for his opinions, found refuge in Prussia and received a pension from Frederick the Great.

In another chapter Prof. W. B. Smith's eloquent article from the Monist works up to the conclusion that "it is a false antagonism between the causative and the teleological conceptions of the universe." Dr. Carus's text is that "nothing moves, nothing stirs nor happens that does not act in agreement with the laws of motion, and there is no harm in it that man's activity takes place in perfect agreement with mechanical laws. A man's a man for a' that!" As for the ancient and modern puzzle--dualism or monism-he says, using Ezekiel's metaphor, "There are not two things, the spirit and the wheels, but there is one reality." "Both spirit and machine are one, and the universal dominance of the laws of form determining the detailed uniformities of motion, commonly called mechanics, is by no means a depressing or melancholy thought. The laws of form are the very means in which spirit reveals itself."

(3) That versatile writer, Prof. de Lanessan, has written a critical history of the relations between these two modes of thought. He considers that evolutionary determinism (transformisme) and animistic supernaturalism (créationisme) are ultimately the only possible theories of the universe. He traces their elements back to the priestly caste of Mesopotamian culture, and carries his account up to Darwin. Considerable space is rightly given to de Buffon, the teacher of Lamarck. Except in the most recent times, the great majority of determinist thinkers have fallen back upon animism to explain the ultimate origin of the universe, or the presence in it of mind. Prof. de Lanessan promises a second volume, dealing with the developments subsequent to Darwin.

(4) If objective science be described as the obverse of human mentality, education is its reverse. From another point of view, as old as the Greeks, education and socialisation-" "politics" in the Greek sense-are complementary. Prof. Graves has written the history of education before the Middle Ages, and from that period to the eighteenth century. He now completes his survey by a volume describing the progress of educational theory and practice, the latter in particular, from the eighteenth century (inclusive) up to the present day.

It is curious to reflect that the "classical" education, still the pabulum of English upperclass youth, was denounced more than a century ago by the French reformer, Rousseau. Equally

NO. 2353 , VOL. 94] 
interesting, is the fact that practically all subsequent educational reformers have been the intellectual heirs of the French iconoclast, such as Pestalozzi, Fellenberg, Froebel, Herbart, and Montessori. While giving prominence to the evolution of education in America, Prof. Graves does not neglect this or other countries, and his account of the German experiments at Neuhof, Königsberg, and Keilhan is detailed. He has an interesting chapter on the introduction in recent years of scientific subjects into curricula, and another on the application of psychological results to the methods of education. The book includes an excellent selected bibliography, very useful in view of the enormous literature of the subject.

(5) The series of scientific and mathematical handbooks edited by Dr. Norrenberg is an encyclopædia for teachers. The fifth volume, on methods of instruction in natural history, by Prof. Schoenichen, of Posen, contains more than six hundred pages, crammed with detailed advice and facts. The author attempts, with success, to cover the whole ground of zoology, botany, and biology generally as an educational subject, and from the teacher's point of view. From psychological pedagogy to gardens and vivaria, he omits nothing that can come into the ken of the schoolmaster. Courses are laid down for the various classes in the Gymnasium, the Real-gymnasium, and the Real and Oberrealschule. The suggestions about methods of drawing, and those on excursions and collecting are excellent. A notable feature is the description of models, their manufacture and use.

Fas est et ab hoste doceri; the book is a triumph of method.

A. E. Crawley.

\section{OUR BOOKSHELF}

The Rubber Industry in Brazil and the Orient. By C. F. Akers. Pp. $\mathrm{xv}+320$. (London : Methuen and Co., Ltd., I9I4.) 6 s. net.

Mr. Akers contrasts in this book the unscientific, and unbusinesslike, rubber-collecting industry of Brazil with the rubber-planting enterprises of the British and Dutch East Indies, which are conducted on more or less scientific lines and with the commercial skill and acumen which distinguishes the two peoples concerned with these East Indian Colonies.

Compared with their competitors in the East, the rubber producers in Brazil have one great advantage - their trees are mature and in their natural habitat. This advantage is believed to account for the general opinion that Brazilian Para rubber is better than the plantation article from the East Indies. Many competent judges maintain that this advantage is illusory, and that properly-prepared East Indian plantation rubber, from well-established NO. 2353, VOL. 94] trees of fair age, is just as good as "fine hard Para," and that the premium obtained by the latter in the markets is the result of conservative prejudice on the part of manufacturers. However that may be, the advantage, supposing it is real, is bound to disappear, in view of the increasing age of the plantations in Ceylon and Malaya, and the untiring efforts of the planters there to improve and unify their methods of preparation.

In all other respects, such as cost and efficiency of labour, good administration and government, business skill and foresight, and last, but not least, the realisation of the necessity for scientific and technical research, the advantages lie with the East Indian producers, and Mr. Akers makes it clear that unless there is a drastic change in the conditions of working in Brazil, the rubber industry there is bound to disappear in the face of the competition of the East Indian plantations.

Mr. Akers probably records little that is new to rubber planters, but his book is none the less interesting on that account, and it can be cordially recommended to all who are interested in the development of this great industry, in which British enterprise and technical skill have played so large a part.

The Beginner's Garden Book: a Text-book for the Upper Grammar Grades. By A. French. Pp. viii +402 . (New York: The Macmillan Company: London: Macmillan and Co., Ltd., 1914.) Price $45.6 d$. net.

There is always much to learn from an American teacher of a rural subject. The science may be superficial, yet he manages to get his students to think about their work and to find reasons for the way in which the work is done. This book is a case in point. It takes the form of an address by a teacher of school gardening to boys engaged in the cultivation of school gardens. The American origin of the book little interferes with its use in this country. The English is almost free from Americanisms, and the cultivation of all our more commonly grown vegetables and flowers is described. The treatment of fruit culture and bastard trenching is inadequate, and grafting and budding are not even mentioned, but, on the other hand, several matters are dealt with that do not often find a place in gardening manuals. The chapters on the saving of seed and on gardening under glass are excellent. A good deal of gardening can be learnt by merely looking at the numerous illustrations.

An Introduction to Geology. By C. I. Gardiner. Pp. xiv +186 . (London: G. Bell and Sons, Ltd., I9I4.) Price 2s. 6d.

Mr. Gardiner is well known as a field-observer, and has added largely, both by himself and with Prof. S. H. Reynolds, to our knowledge of Silurian areas. He now attracts others to his favourite studies by a clearly written introduction to geology, which will be of especial interest to dwellers in the English midlands. General principles are supported by more detail than is usual in elementary works, and this method carries convic- 